\title{
CISD1 wt Allele
}

National Cancer Institute

\section{Source}

National Cancer Institute. CISD1 wt Allele. NCI Thesaurus. Code C113134.

Human CISD1 wild-type allele is located in the vicinity of $10 \mathrm{q} 21.1$ and is approximately 21

$\mathrm{kb}$ in length. This allele, which encodes CDGSH iron-sulfur domain-containing protein 1 , plays a role in the modulation of both cellular respiration and iron-sulfur clusterdependent redox reactions. 